\title{
鉄道利用者の帰宅途中における立ち寄り駅の選択行動について CHOICE BEHAVIOR OF STOPOVER-STATION BY RAILWAY USERS ON THEIR WAY HOME
}

\author{
大佛俊泰*, 岩淵紗葵**, 沖 拓弥*** \\ Toshihiro OSARAGI, Saki IWABUCHI and Takuya OKI
}

\begin{abstract}
Railway commuters often make stopover at various stations for eating or shopping on their way home. In this paper, we construct a multinomial logit model, which describes their choice behavior of stopover-stations on their way home. A nalyzing the person trip data obtained in three different time $(1988,1998$, and 2008) by the proposed model, we discuss the attractiveness of stopover-stations from the viewpoint of attributes of railway commuters and the purpose of stopover. In addition, as an application of the model, we estimate the change of attractiveness of stopover-stations, by assuming increase of the number of commercial facilities around the specific stations or the change of railway network.
\end{abstract}

Keywords : person trip survey, multinomial logit model, stopover behavior, railway station パーソントリップ調査，多項ロジットモデル，立ち寄り行動，鉄道駅

\section{1. はじめに}

\section{(1) 研究の背景と目的}

鉄道網の拡張や駅周辺地域の再開発などを背景として，鉄道利用 者の移動行動は多様化している。鉄道利用者の大半を占める通勤・ 通学者の行動に着目すると, 自宅と通勤・通学先の間を往復する単 純な移動行動は減少しており, その一方で, 帰宅途中に買い物・食 事・習い事などの目的で, 他の場所に立ち寄る行動が増加している。 こうした立ち寄り行動の実態を把握することは, 安全で快適な鉄道 運行や駅舎の設計だけでなく, 駅周辺地域の活性化について検討す る上でも重要である。

近年，買い物等を目的とする帰宅途中の立ち寄り行動について， 様々な視点から分析がなされている。足立・吉川 ${ }^{1)}$ は通勤者が退 社後に立ち寄りやすい場所の空間構成について分析している。ま た, 田中 ${ }^{2)}$ は, 帰宅途中の立ち寄り可能者数の最大化を図るサー ビスの提供場所と開始時刻を決定するモデルを構築することで，鉄 道駅の時空間的な立ち寄りや寸さについて分析している。栗田・本 間 ${ }^{3)}$ は空間相互作用モデルを拡張することで, 発生ゾーンと到着 ゾーンの間に立ち寄りゾーンが介在するモデルを構築しており， 従来までの単純な 2 地点間の空間的相互作用を拡張しており興味深
い。小玉ら ${ }^{4)}$ は都市内就業者に対してアンケート調查を実施し, 通勤手段や利用駅の特性が立ち寄り行為に与える影響について考察 している。

立ち寄り行動を組み込んだ多項ロジットモデルを用いて，施設選 択行動について分析した研究事例もある。磯野・岸本 ${ }^{5)}$ は図書館 の選択行動について, 徳永・貞広 ${ }^{6)}$ は銀行のATM の選択行動につ いて, それぞれモデル化し, 最適規模や最適配置について検討して いる。また, 前川・倉内 ${ }^{7)}$ は, 買物行動を類型化することで, 目 的地の選択行動をモデル化している。

以上のように，主目的ではなく副次的な目的で立ち寄る，いわゆ る「ついで利用」についての研究は多い。しかし, 通勤・通学者が 買い物等の目的で行う立ち寄り行動を，立ち寄る駅の選択行動とみ なして議論した研究は少ない。そのひとつに，鉄道駅を選択肢とみ なして買い物場所選択モデルを構築した李ら ${ }^{8)}$ の研究がある。個 人属性や習慣, 品目間の相性など, 選択行為に及ぼす影響を吟味し ている点で参考となり興味深いが, 自宅の最寄り駅と通勤・通学先 の最寄り駅以外の具体的な立ち寄り駅については議論しておらず, また，立ち寄り行動の経年変化についても考察されていない。

本稿では，鉄道を利用する通勤・通学者が，買い物・食事・習い

\footnotetext{
本稿は文献 12)～15)をもとに新たに分析を加え加筆・修正したものである。

* 東京工業大学環境 · 社会理工学院 教授 · 博士 (工学)

** 東京工業大学大学院情報理工学研究科修士課程

*** 東京工業大学環境 $\cdot$ 社会理工学院 助教 $\cdot$ 修士 (工学)
} 
事などの目的で帰宅途中に行う立ち寄り行動について検討し，この 際に立ち寄る駅を推定するモデル（立ち寄り駅選択モデル）を構築 する。具体的には, 個人ごとに異なる居住地と通勤・通学先の位置 関係や，立ち寄る駅の周辺環境を考慮した多項ロジットモデルを構 築する。時点の異なるデータを用いてモデルを推定し, 立ち寄る人 の属性や時点に応じて変化する立ち寄り駅の魅力度を定量的に分析 寸る。さらに, 立ち寄り駅選択モデルを応用して, 鉄道駅周辺の環 境や鉄道網が変化した場合を想定したシミュレーションを実行し， 立ち寄り駅の魅力度の挙動について考察を試みる。

\section{(2) 本稿の構成}

第 2 章では, 立ち寄り駅選択モデルの定式化を行い, 各変数の 定義や数值の算出方法について述べる。第 3 章では, パーソント リップ調査データを用いて, 分析対象駅と分析対象者を抽出する 方法について述べ, 抽出した対象駅・対象者のプロフィールを 整理する。第 4 章では, パーソントリップ調査データから抽出し た通勤・通学者のトリップ情報から, 立ち寄り駅選択モデルの未 知パラメータを推定し, 属性別・時点別の立ち寄り行動特性を定 量的に把握する。第 5 章では, 駅周辺地域における商業施設の増 加や，異なる鉄道事業者間での相互直通運転などを仮想的に設定 して, 立ち寄り駅の魅力度の変化や立ち寄り行動の変化をシミュ レートすることで, 本稿で構築した立ち寄り駅選択モデルの応用 可能性を示す。

\section{2. 立ち寄り駅選択モデルの構築}

\section{(1) モデルの定式化}

立ち寄り行動の定義を図 1 に示してある。通勤・通学の目的で, 自宅の最寄り駅（居住地駅） h から, 通勤・通学先の最寄り駅（通 勤・通学駅）i 几移動した個人 n が, 帰宅途中に買い物や食事など の目的で駅 j に立ち寄る行動について考える。このとき, 駅 i から 駅 j 几 移動する際の交通手段は問わず，駅 i と駅 $\mathrm{j}$ が同一である場 合も含めて考える。このとき，個人 $\mathrm{n}$ は立ち寄る際に享受する効用 を最大化するように行動する（効用が最大となる駅を選択する）と 仮定し，通勤・通学者による立ち寄り駅 j の選択行動を多項ロジッ トモデル ${ }^{9)}$ を用いて記述する。

まず，定式化に必要となる各変数を以下のように定義する。個人 $n$ の立ち寄り駅 $\mathrm{j}$ の選択肢集合を $A_{n}\left(j \in A_{n}\right)$ ，個人 $n$ が駅 $\mathrm{j}$ に立 ち寄ることで得られる効用の確定項（立ち寄り駅の魅力度）を $V_{j n}$ と表す。このとき, 立ち寄り駅 j を選択する確率 P j は, 確率効用 理論に基づき多項ロジットモデルを用いて式 (1) で表現することが できる。以下では，このモデルを「立ち寄り駅選択モデル」と呼ぶ。

$$
P_{j n}=\frac{\exp \left[V_{j n}\right]}{\sum_{j^{\prime} \in A_{n}} \exp \left[V_{j^{\prime} n}\right]} \quad\left(j, j^{\prime} \in A_{n}\right)
$$

次に, 効用関数 $V_{j n}$ として, 以下の線形モデルを考える。

$$
V_{j n}=\sum_{k} \theta_{k} X_{j n k} \quad\left(j \in A_{n}\right)
$$

ただし， $\theta_{\mathrm{k}}$ は未知パラメータ， $\mathrm{X}_{\mathrm{jnk}}$ は個人 $\mathrm{n}$ の選択肢 $\mathrm{j}$ に関する $\mathrm{k}$ 番目の特性変数を示す。

（2）特性変数 $X_{j n k}$ の定義

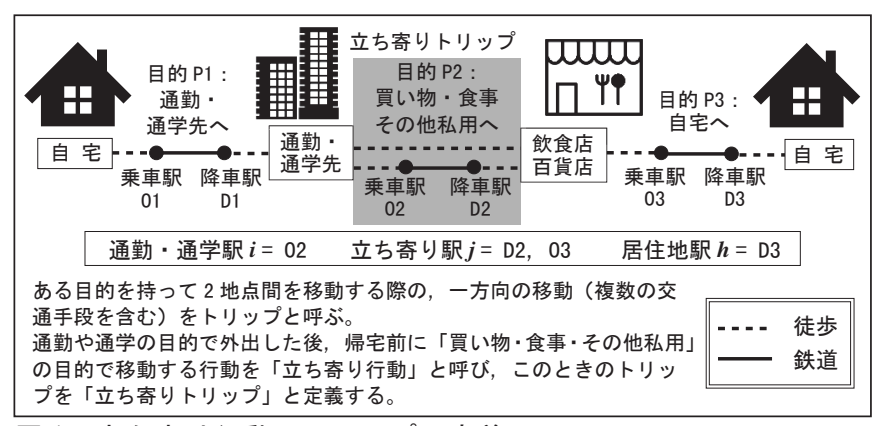

図 1 立ち寄り行動・トリップの定義

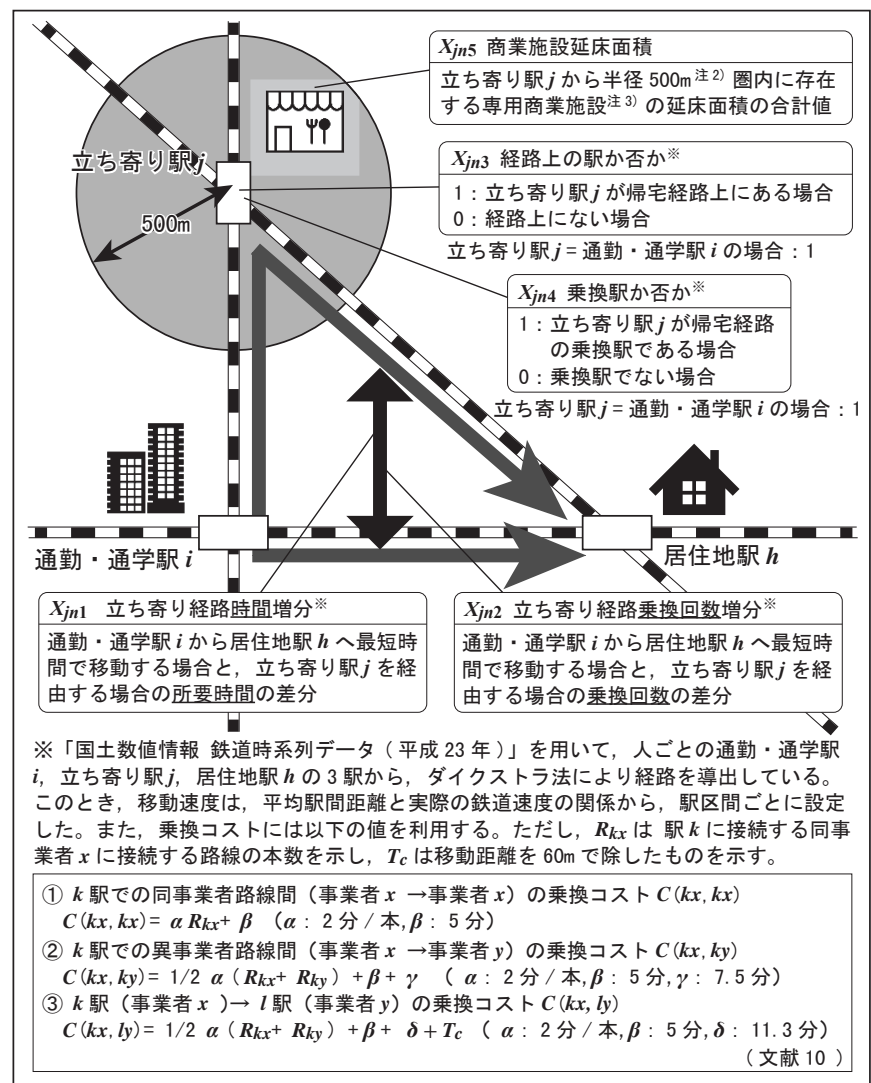

\section{図 2 特性変数 $X_{j n k}$ の定義}

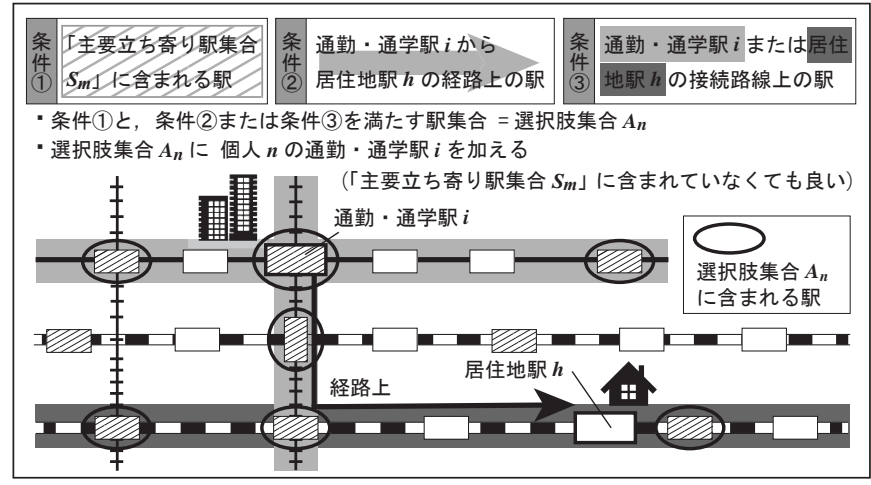

図 3 選択肢集合 $A_{n}$ の設定条件

立ち寄り駅選択モデルにおける特性変数注 1) の定義を図 2 に示し てある。まず, 立ち寄り駅の選択に際しては, 帰宅までの移動に要 する所要時間の増加や乗換回数の増加が影響すると考えられる。そ こで, これらを変数 $X_{j n 1} \sim X_{j n 4}$ を用いて記述する。このとき, 乗 換回数の増加に伴う負の効用（乗換コスト）は所要時間の増分に換 算して考える（文献 10 参照）。各個人の移動経路は，ダイクスト 
ラ法を用いて, 所要時間が最短となる経路として推定する。また, 周辺に店舗の数や種類が豊富な駅は, 立ち寄り駅としての魅力度が 高いと考えられる。そこで, 魅力度は駅周辺の商業施設の合計延床 面積に比例するものと考え, 変数 X jn5 を作成した。

（3）選択肢集合 $A_{n}$ の設定

多項ロジットモデルでは，個人 $\mathrm{n}$ ごとに立ち寄り駅の選択肢集 合 $A_{n}$ を定義する。具体的には，(1)立ち寄り駅として選択される 頻度の高い上位 $\mathrm{m}$ 駅の集合（主要立ち寄り駅集合） $S_{m}$ に含まれ る駅であり，かつ，(2)通勤・通学駅 i から居住地駅 h までの経路 上の駅, もしくは, (3)通勤・通学駅 i または居住地駅 h の接続路 線上の駅の集合を，個人 $n$ の選択肢集合 $A_{n}$ とした注 ${ }^{4 ｝ \text { （図 3) }$ 主要立ち寄り駅集合 $S_{m}$ の具体的な決定方法は, 図 4 に示してあ る。また, 選択肢集合 $A_{n}$ には個人 $\mathrm{n}$ の通勤・通学駅 $\mathrm{i}$ （必ずしも 主要立ち寄り駅集合 $S_{m}$ の駅とは限らない) を含めて考える。こ のことで, 通勤・通学先周辺地域における立ち寄り行動について も考える注 5)。

\section{3. 分析対象駅 · 分析対象者の設定方法}

\section{(1) 分析対象駅集合の決定}

本稿では，東京都市圈パーソントリップ調査データ (S63, H10，H20）（以下，PT データ）から立ち寄りトリップを抽出し, 分析に用いる注 6)。3 時点す心゙てにおいて, 立ち寄り駅として選択 される頻度の高い上位 40 駅注 7) $(m=40)$ ， 寸なわち，主要立ち寄 り駅集合 $S_{40}$ を, 本稿では分析対象駅として抽出した。主要立ち寄 り駅集合 $S_{40}$ に含まれる, 具体的な駅名を図 4 に示してある。新宿 駅・池袋駅・渋谷駅のような都心に立地する大規模駅のほか，立川 駅・八王子駅・町田駅など，郊外に立地する駅も含まれている。

\section{(2) 分析対象者の抽出方法}

鉄道（地下鉄を含む/以下同様）利用者全体のトリップの経年変 化を図 5 に示してある。1 日に 1 回以上鉄道を利用する人の，1 日 の合計トリップ数をみると（図 5(a)），経年的に 2 トリップの人の 割合が減少し，3トリップ以上の割合が増加している。移動目的の 分類方法に基づき，1日のトリップをパターン化（文字羅列化）す ると（図 5(b)）, 経年的に「WH（通勤・通学先へ赴き, 立ち寄り せずに帰宅する行動）」の占める割合が減少し，「その他」が増加 していることがわかる。すなわち, 鉄道利用者のトリップが多様化 していることを示唆している。また，H20には，「WSH（通勤・ 通学先一赴き, 買い物・食事・習い事などの立ち寄り行動をしてか ら帰宅する行動）」の割合が「SH（直接，買い物・食事・習い事 のために外出し, その後, 帰宅する行動）」の割合の約 2 倍となっ ている。

そこで, 本稿では立ち寄り行動の代表的な行動パターンとして 「WSH」に着目する。まず，PT データから図 5 に示す条件(1) と条 件(2)を満たし，かつ，条件(3)または条件(4)を満たす鉄道利用者を抽 出する。さらに, 立ち寄った駅が選択肢集合 $A_{n}$ に含まれる個人 $n$ を分析対象者とする注9) (S63:3,958 サンプル, H10:4,652 サンプル，

H20 : 4,794 サンプル)

\section{(3) 分析対象者の概要}

図 5 の条件(1)〜(4)の下で抽出した分析対象者の属性別割合を時点 別に求め図 6 に示した。女性や高年齢層の割合が経年的に増加して

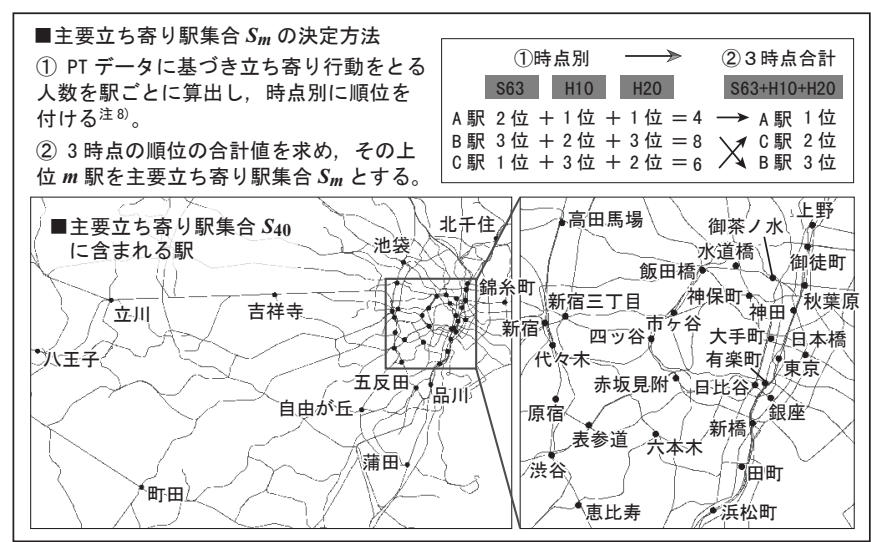

図 4 主要立ち寄り駅集合 $S_{m}$ の決定方法と分析対象駅 $(m=40)$

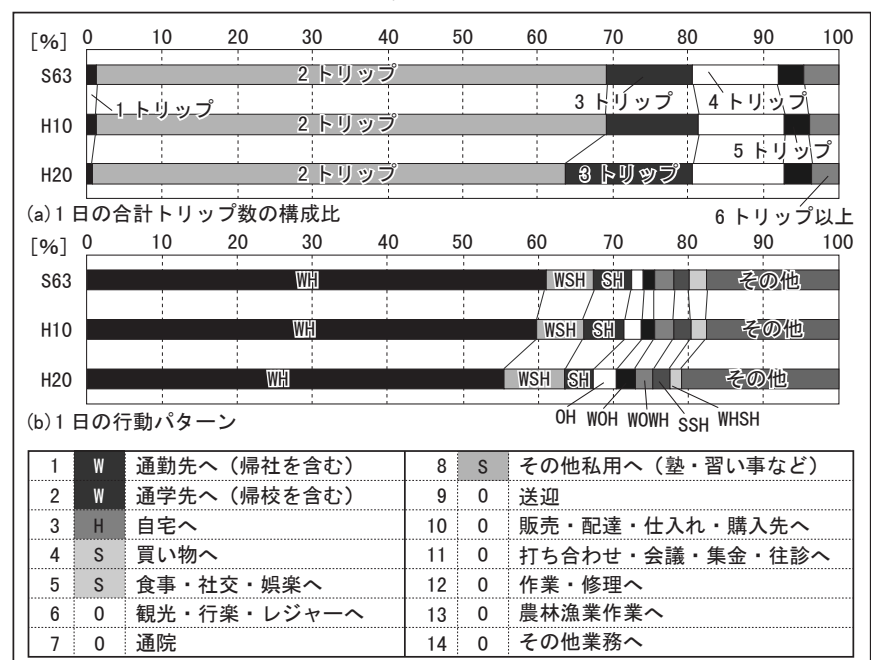

\section{口 分析対象者の抽出条件}

条件(1) 1 日の合計トリップ数が 3 である個人の中で, 移動の目的が「W $\rightarrow \mathrm{S} \rightarrow \mathrm{H} 」$ の順である。

条件(2) $1 \cdot 3$ トリップ目の交通手段は「鉄道」に限定し，2トリップ目（立ち寄りトリッ プ）の交通手段は問わない。

条件 (3) [2 トリップ目の交通手段 = 鉄道 ] 降車駅 D2 と乗車駅 03 は主要立ち寄り駅集合 $S_{m}$ に含まれる駅であり，降車駅 D1 は東京都内の駅である。(01〜D3 は図 1参照)

条件(4) [2 トリップ目の交通手段 = 鉄道以外 ] 降車駅 D1 と乗車駅 03 は東京都内の駅で ある。

\section{図 5 鉄道利用者全体の行動変化と分析対象者の抽出条件}

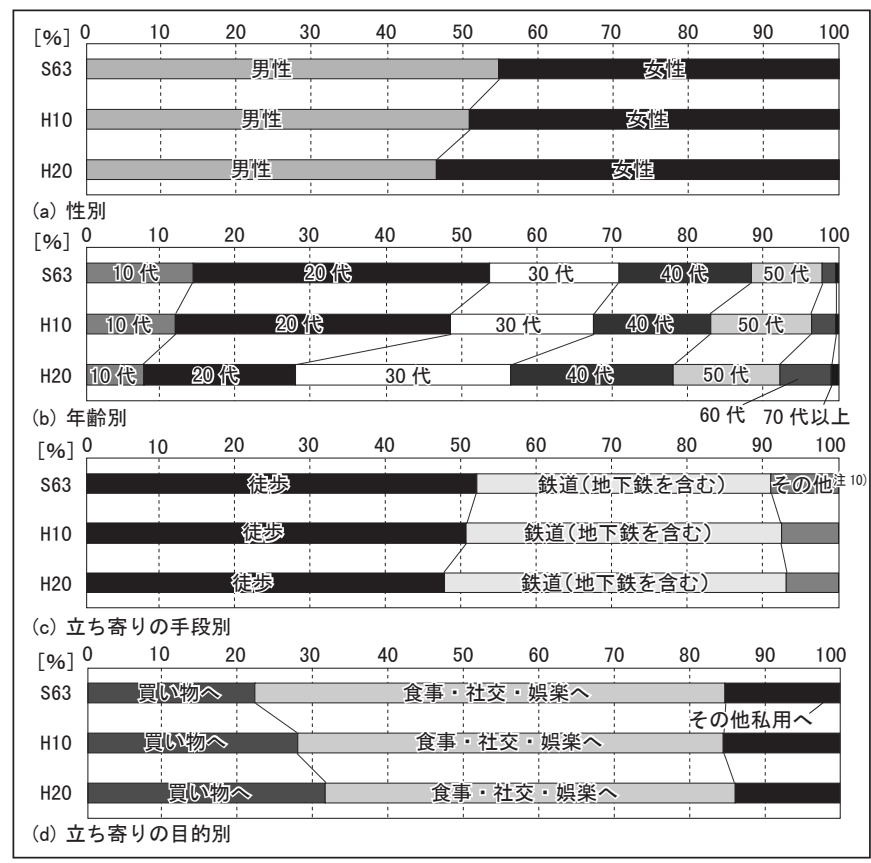

図 6 分析対象者の属性の経年変化 
いることがわかる（図 6(a)(b)）。主に通勤者の性別や年齢の構成比 がこの 20 年間で大きく変化したことに起因すると考えられる。ま た, H20 に 20 代の割合が激減しているのは, 少子高齢化の人口動 態が現れていると考えられる。さらに, 立ち寄りする際の移動手段 についてみると（図 6(c)）, 徒歩による通勤・通学先周辺地域での 立ち寄りが減少し，鉄道を利用した立ち寄り行動が増加しており， モビリティが向上していることがわかる。また，買い物を目的とす る立ち寄りの割合が増加している。昨今のいわゆる「駅ナカ」の充 実など，新たな商業空間が出現したことにより，帰宅途中での食事 や買い物が活性化されている可能性もある（図 6(d)）

分析対象者の立ち寄り先での滞在時間（2回目のトリップの終了 時刻から 3 回目のトリップの開始時刻までの時間）と，立ち寄り先 への到着時刻（2回目のトリップの終了時刻）の頻度分布を図 8 に 示してある。まず，買い物での立ち寄り滞在時間については，3 時 点（S63〜H20）でほとんど差がない。しかし, 到着時刻について は，S63には $20 \sim 21$ 時台が半数以上を占めていたが，H20になる と 21 時以降の遅い時間へとシフトしている。一方，食事・社交・ 娛楽での立ち寄りに着目すると, 滞在時間は 2 時間未満の割合が減 少し，3 時間以上の割合が増加している。さらに, 到着時刻は, 20 時台の割合が減少し，22 時台の割合が増加している。すなわち, 立ち寄り行動が発現する時刻は, 経年的に遅い時刻へシフトしてお り，食事・社交・娛楽については滞在時間も長くなっている。この 背景には，鉄道・バスの深夜運行や商業施設の深夜営業の開始・定 着, 勤務時間の長時間化など, 社会環境の変化が影響していると考 えられる。

\section{4. 立ち寄り駅選択モデルの推定}

\section{（1）モデルの推定精度}

立ち寄り駅選択モデルのパラメータ $\theta_{\mathrm{k}}$ は, ニュートン・ラプソ ン法を用いて最尤法により推定した。変数間でのパラメータの大小 関係を把握しやすくするため, 時点・変数ごとに基準化したデータ （平均 0 ，分散 1) を用いて推定している。

各時点における立ち寄り者数のモデルによる推定值と, PT デー タから求めた実績值を駅別に比較すると，モデルの記述精度は良好 であることがわかる（図 8)。錦糸町駅が全時点で過大推計となっ ているのは, PT データでは東京駅や御茶ノ水駅に立ち寄っている 人の多くが，モデルでは錦系町駅に立ち寄ると誤推定されているこ とによる。具体的には，東京駅周辺に立地する大規模事務所ビルの 低層部には多くの商業施設が併設されているが，分析に用いたデー 夕に反映されていないこと（建物用途同定の問題）が原因と考えら れる。また，池袋駅での立ち寄り者数は，S63と H20については， 推定精度は高いが, H10 については過大推計となっている。池袋駅 周辺では, S63 から H10 にかけて, 商業施設が大幅に増加したが, 立ち寄り者数の増加として顕在化するまでには一定の時間を要した 可能性がある。3 時点のモデルの尤度比は経年的に上昇しており, モデルに組み込んだ説明変数と立ち寄り駅の魅力度との関係は, よ り明瞭になっているといえる。

\section{（2）モデルの推定パラメータの解釈}

モデルの推定パラメータを図 9 に示してある。時点によらず，立 ち寄る際の増加時間や乗換回数が抵抗となり魅力度を下げることが

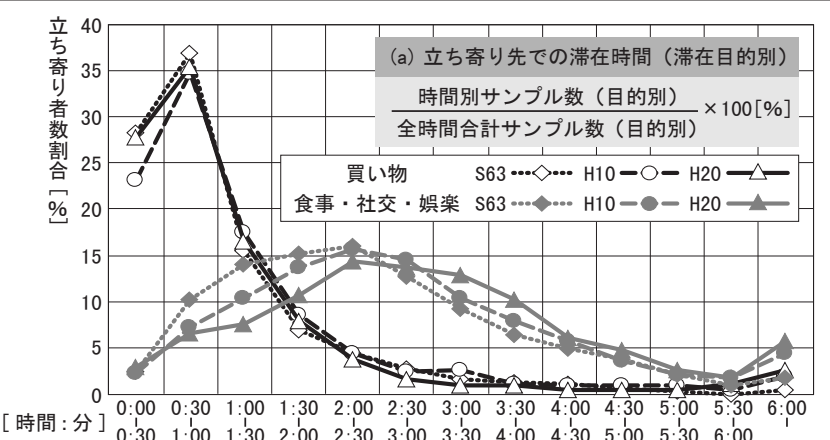

[ 時間: 分] \begin{tabular}{lllllllllllll}
\hline & 0 \\
0
\end{tabular}

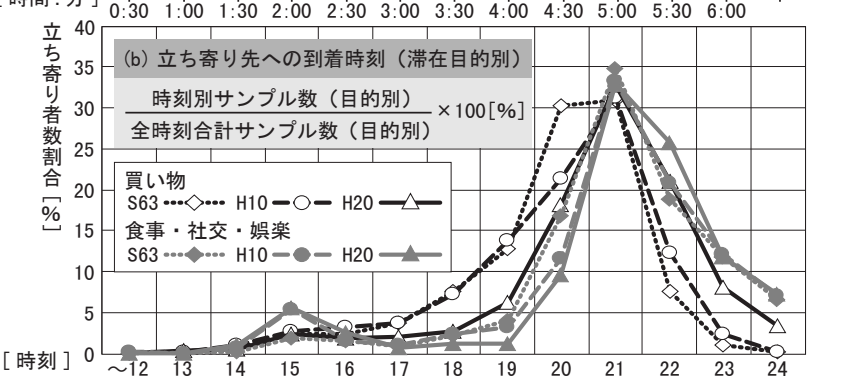

図 7 立ち寄り先への到着時刻と滞在時間の頻度分布
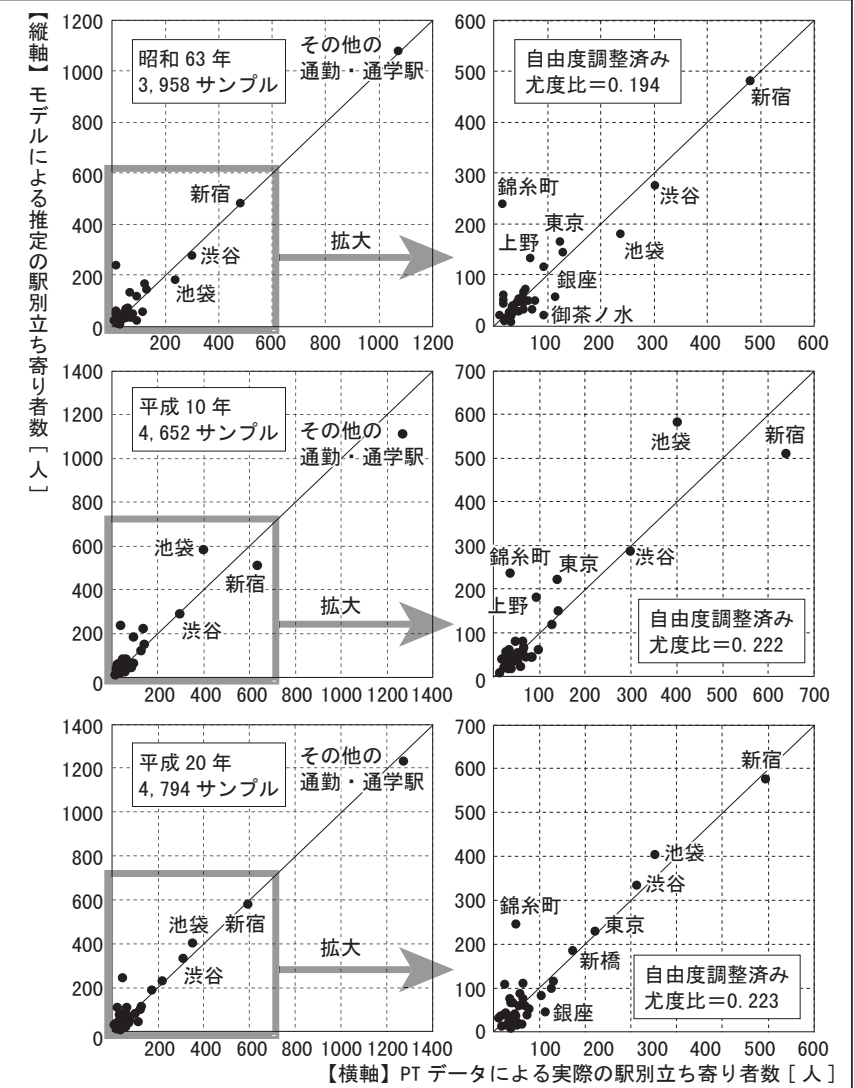

図 8 モデルの推定精度（駅別の推定立ち寄りサンプル数）

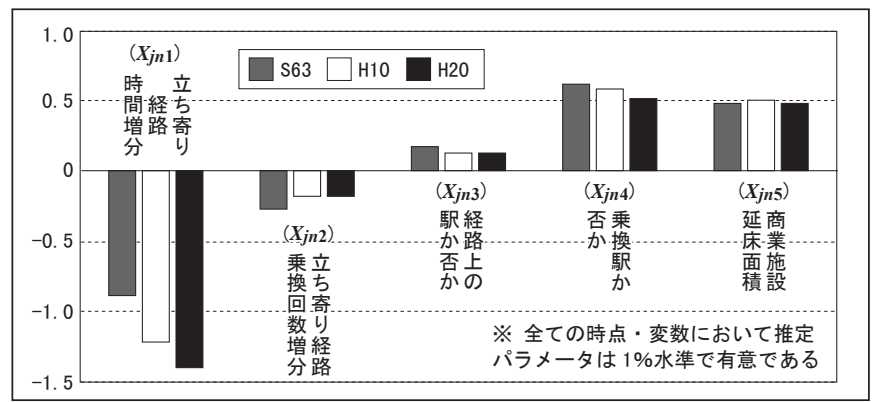

図 9 モデルの推定パラメータ 
わかる。また, 乗換駅であること, 通勤・通学経路上の駅であるこ と, 駅周辺の商業施設の大きさが, 立ち寄り駅としての魅力度を向 上させることが見て取れる。時点別に比較すると, 立ち寄る際の増 加時間（変数 $X_{j n 1}$ ）に対寸る抵抗が, 他の変数と比べて経年的に大 きくなっていることがわかる。近年のインターネットを介した精緻 なナビゲーション・サービスの出現により, 都市内移動に要する時 間に敏感になっている可能性もある。一方, 変数 $X_{j n 3}$ と变数 $X_{j n 4}$ の推定パラメータは他の変数と比べて経年的に值が小さくなってお り，乗換駅や経路上の駅ではない駅も選択されやすくなっている。

\section{（3）属性別推定パラメータの解釈}

(1) 性別

分析対象サンプルを性別で分類し，モデル推定を行った。その結 果を図 10(1) に示してある。男性の場合, 変数X $\mathrm{jn1}$ のパラメータ值 が経年的に負に大きくなっていることから，立ち寄る際に増加する 乗換回数よりも, 時間増加に対する抵抗感が大きくなっていること がわかる。また, 時点によらず, 男性については変数 X $\mathrm{jn} 4$, 女性に ついては変数 $X_{j n 5}$ のパラメータ值が正に大きい。すなわち, 男性 は乗換駅であること, 女性は商業施設の延床面積が大きいことを重 視して, 立ち寄り駅を選択している。

(2) 年齢別

分析対象サンプルを年齢別で分類し，モデル推定を行った。その 結果を図 10(2) に示してある（サンプル数が十分でないため, 年齢 区分を時点ごとに設定している）。年齢別の推定モデルの尤度比を 比較すると, どの時点についても, 25 歳未満よりも 25 歳以上の方 が尤度が高い。2 5 歳未満のサンプルには, 行動特性が大きく異な る通勤者と通学者が混在しているためと考えられる。

高年齢層ほど, 変数 $X_{\mathrm{jn} 1}$ のパラメータ值は負に大きくなり, 変 数 $X_{j n 4}$ のパラメータ值は正に大きくなっている。すなわち, 高年
齢層ほど，立ち寄る際に増加する移動時間に対する抵抗が大きく， 立ち寄り駅としての魅力度は乗換駅で高いことがわかる。また, 若 年齢層ほど, 時点によらず, 変数 X jn5 のパラメータ值は正に大き く, 商業ポテンシャルの高い駅が選択されやすいことを示してい る。

\section{(3) 目的別}

分析対象サンプルを立ち寄る際の目的別で分類し，モデル推定 を行った。その結果を図 10(3)に示してある。目的別の推定モデ ルの尤度比を比較すると, その他私用を目的とする人の適合度は 比較的低い。その他私用（塾や習い事）を目的とする人の選択行 動は多様であり，これを記述するための説明変数が十分に組み込 まれていないためである。しかし，買い物を目的とする人につい てはモデルの適合度は高く良好である。

変数 $X_{j n 1}$ と変数 $X_{j n 5}$ については, 買い物を目的とする人のパラ メータ值がそれぞれ負と正に大きい。すなわち，他の目的の人より も立ち寄る際の増加時間への抵抗が大きく, また, 周辺に商業施設 が多い駅が立ち寄り駅として選択されやすいことが確認できる（特 に変数 $X_{j n 1}$ では, 経年的に負に大きくなっている）。また, 変数 $X_{j n 4}$ については, 食事・社交・娛楽を目的とする人のパラメータ值 が正に大きく，乗換駅が選択されや寸いことがわかる。すなわち， 買い物を目的とする人は, 移動に要する時間を重視しており, 食事・ 社交・娛楽を目的とする人は, 複数人で待ち合わせる際に便利な乗 換駅を重視して, 立ち寄り駅を選択していると推察される。

\section{5. 立ち寄り駅選択モデルの応用}

(1) 分析の視点

以下では推定した立ち寄り駅選択モデルを用いた簡便なシミュ レーション分析を試みる。具体的には, 駅周辺環境や鉄道路線を

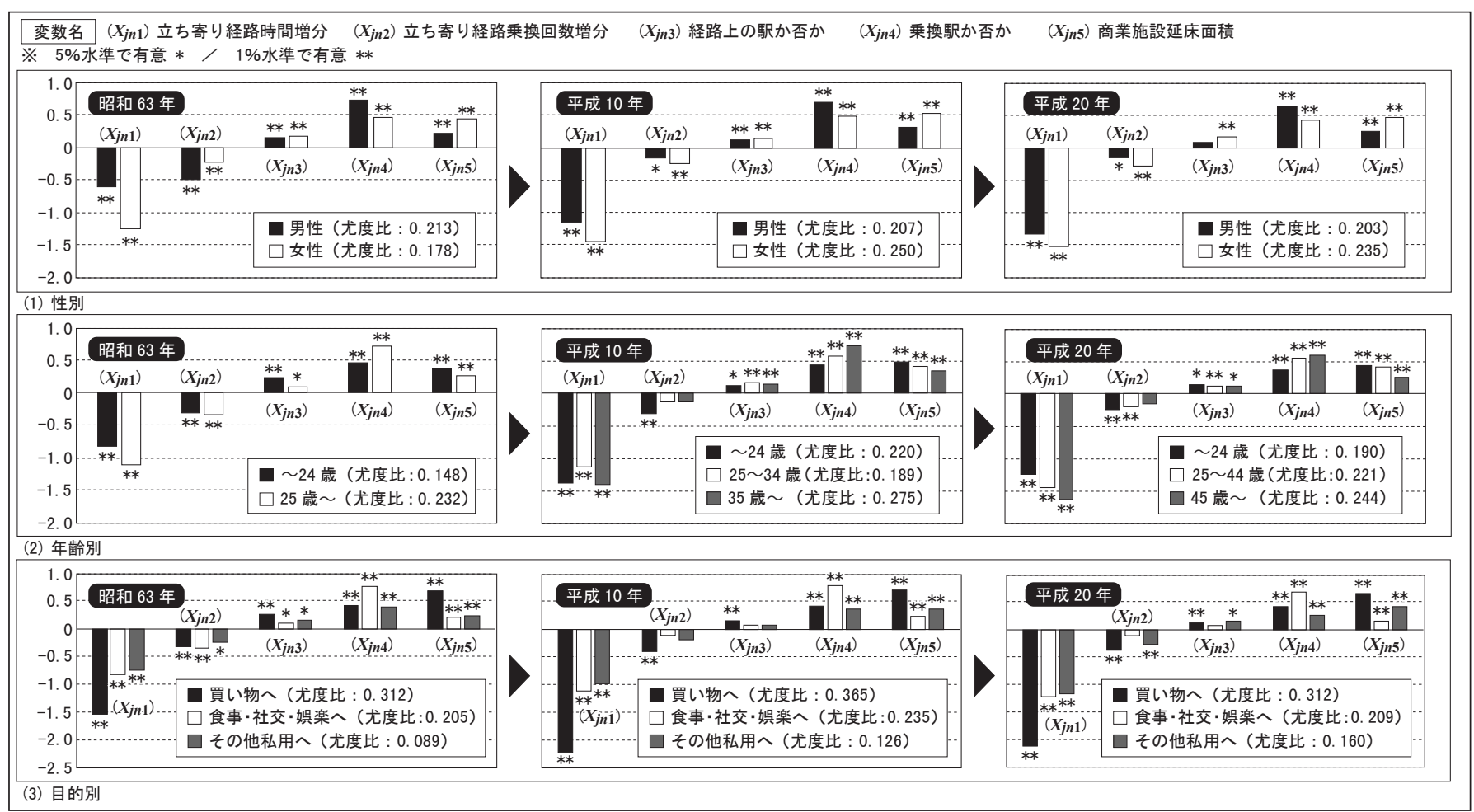

図 10 モデルの推定パラメータ（属性別） 
仮想的に変化させて, 各駅における立ち寄り者数の変化について 考察する。すなわち, ある特定の駅周辺の環境が変化したり, ま たは，異なる鉄道事業者間で相互直通運転を実施するなどの変化が 生じた場合に, 立ち寄り駅としての魅力度が各駅でどのように変化 し, また, その結果, 立ち寄り者数がどの程度変化するかについて 考察する。

\section{（2）特定の駅周辺における商業施設増減による魅力度変化}

近年，鉄道駅の周辺では商業施設は増加傾向にある。例えば，渋 谷駅周辺地域には，H40 頃に完成予定である大規模な再開発計画が ある。そこで, 渋谷駅周辺地域で商業施設が増加した際の, 立ち寄 り駅の魅力度変化を，モデルを用いて推定した（図 11）。具体的 には, 渋谷駅から $500 \mathrm{~m}$ 圈内の商業施設延床面積（変数 $X_{j n 5}$ ）の值 が仮に 10 万 $\mathrm{m}^{2}$ 増加した場合注 $\left.{ }^{11}\right)$ の立ち寄り者数の変化率（H20を 基準とした值）を駅ごとに算出した。渋谷駅では H2O 時点と比較 して約 $12 \%$ 立ち寄り者数が増加すると推定された。一方, 渋谷駅 に隣接する表参道駅・恵比寿駅・原宿駅だけでなく, 自由が丘駅に おいても立ち寄り者数の減少率が大きい。これは, 渋谷駅から横浜 方面へ帰宅寸る際の自由が丘駅への立ち寄り行動が, 減少すること を示している。しかし, 立川駅や町田駅など, 渋谷駅から離れた郊 外, 東京駅周辺, 総武・中央線上の駅についてはほとんど変化がな い。

\section{（3）異事業者間での相互直通運転による魅力度変化}

異なる鉄道事業者間で相互直通運転を行うことによる，立ち寄り 駅の魅力度の変化を推定する。具体的には, 渋谷駅において東急東 横線と副都心線が直通運転を開始し, 中目黒駅における日比谷線と 東急東横線の直通運転を中止した場合を想定する（平成 25 年に実 施された実際の事例）。モデルの変数 $\mathrm{X}_{\mathrm{jn} 1} \sim \mathrm{X}_{\mathrm{jn} 4}$ を構成する際に, 直通運転となる路線間での乗換コスト（図２参照）を０に設定する ことで「直通の状態」を仮想的に構成し，「直通でない状態」との 立ち寄り者数の差分を求めた（図 12）。相互直通運転の開始によ り, 副都心線上の渋谷駅や新宿三丁目駅, 池袋駅の立ち寄り駅とし ての魅力度が高まることがわかる。一方, 渋谷駅や池袋駅に近く, 立ち寄り者数が最も多い新宿駅や, 渋谷駅に近接する代々木駅・原 宿駅の魅力度が相対的に若干低下している。また, 隣接関係にない 銀座駅や六本木駅でも立ち寄り者数が減少している。これは, 相互 直通運転の開始により, 東横線利用者が日比谷線や銀座線に流入し にくくなるためと考えられる。

\section{6. まとめ}

鉄道を利用する通勤・通学を対象として, 帰宅途中における立ち 寄り駅の選択行動を多項ロジットモデルを用いて記述した。モデル の推定精度は経年的に上昇しており, 採用した説明変数が立ち寄り 駅の魅力度を良好に記述できることを示した。また，推定パラメー タの值から, 各説明変数が立ち寄り駅の魅力度に及ぼす影響の程 度, および, その経年変化を把握した。帰宅経路の乗換駅や, 周辺 に商業施設が多い駅は, 時点によらず立ち寄り駅としての魅力度が 高いが，立ち寄る際の増加時間に対する抵抗は, 経年的に大きく なっていることを示した。さらに，鉄道利用者のサンプルを属性別 に分類し, それぞれモデルを推定した。性別, 年齢, 立ち寄りの目 的によって異なる, 立ち寄り駅の選択性向を定量的に把握し, 以下

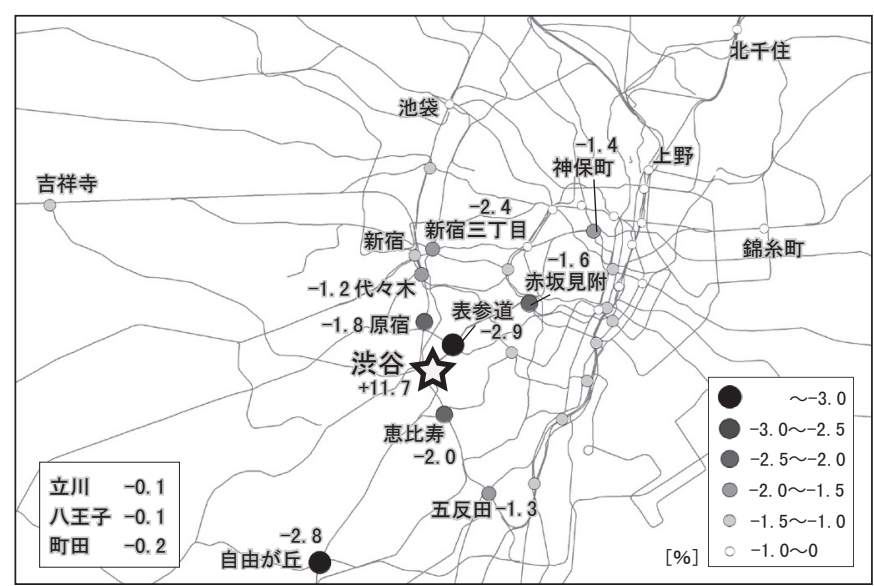

図 11 渋谷駅周辺の商業施設増加による魅力度変化

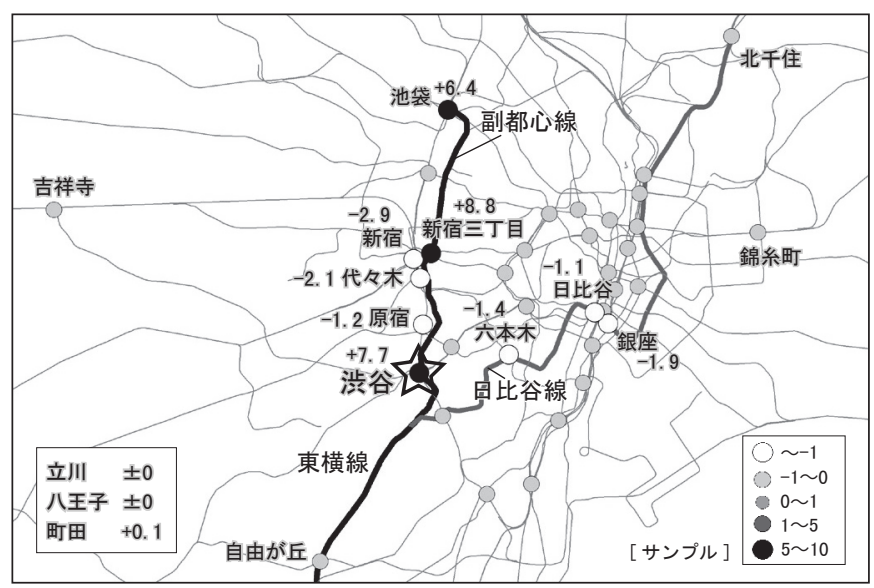

図 12 渋谷駅における相互直通運転による魅力度変化

の知見を得た。

(1)男性は乗換駅を, 女性は商業集積が大きい駅を立ち寄り駅として 選好する。

(2)高年齢層ほど立ち寄る際の増加時間に対する抵抗が大きく, 若年 齢層ほど商業ポテンシャルの高い駅の魅力度が高い。

(3)買い物を目的とする立ち寄り行動では，立ち寄る際の増加時間へ の抵抗が大きく, 食事・社交・娛楽を目的とする立ち寄り行動で は, 待ち合わせに便利な乗換駅の魅力度が高い。こうした違いに は行動を共にする人数が関連している可能性がある。

最後に, 立ち寄り駅選択モデルを用いて, 駅周辺で商業施設が増 加した場合や，異なる鉄道事業者間が相互直通運転を開始した場合 を仮想的に設定し，立ち寄り駅としての魅力度の変化，および，立 ち寄り者数の変化を推定した。その結果, 商業施設が増加する駅に 隣接する駅での立ち寄り者が大きく減少し, また, 相互直通運転を 実施する路線上の駅の魅力度が高まり, その駅に接続する別の路線 上の駅の魅力度が低下寸ることを確認した。

以上より，鉄道を利用する通勤・通学者の帰宅過程における立ち 寄り行動に影響を及ぼす要因を抽出し, 立ち寄り行動を記述するモ デルを構築した。さらに, 駅周辺地域での再開発や鉄道事業者間で の相互直通運転に伴って变化する立ち寄り行動の変化を予測するな ど, 本稿で構築した立ち寄り駅選択モデルの応用の可能性を示し た。 
注

注 1）図 2 に示寸変数の他に「大規模商業施設数（専用商業施設の中で延床 面積が $3,000 \mathrm{~m}^{2}$ 以上の建物の数）」, 「立ち寄り駅 $\mathrm{j}$ の周辺にある駅の数」, 「駅が設置された年」，「駅に接続する始発路線の本数」などを用いて 分析したが，推定パラメータの正負の論理性や統計的有意性の視点から 説明変数から除外した。

注 2）駅から半径 $500 \mathrm{~m}$ 圏内のエリアであれば, 駅周辺に位置する立ち寄り 先を十分に考慮できるものとした ${ }^{11)}$

注 3 ) 東京都建物現況調査（区部: 平成 18 年・平成 8 年・昭和 61 年, 多摩地域: 平成 19 年，平成 9 年，昭和 62 年）を使用している。東京都建物現況調 査では, 建物用途が複数に分類されている。その中で, 商業に関する主 用途は, 「専用商業施設」, 「住商併用建物」, 「宿泊・遊興施設」, 「スポー ツ・興行施設」の 4 種である。これらの中で, 推定パラメータが 3 時点 すべてでモデルが有意となり, かつ, 最も尤度比が高い「専用商業施設」 を採用している。

注 4）選択肢集合 $A_{n}$ に含まれる駅数は, 個人 $\mathrm{n}$ の居住地駅 $\mathrm{h}$ と通勤・通学駅 i の位置関係によって異なる。例えば $\mathrm{m}=40$ において, H20では，選択肢 集合 $A_{n}$ に含まれる駅数の平均值は 14.7 , 標準偏差は 8.20 であり, S63 と H10 も同程度である。

注 5）通勤・通学駅 i の中で，主要立ち寄り駅集合 $S_{m}$ に含まれない駅につい ては,「その他の通勤・通学駅」という選択肢として扱う。なお，この

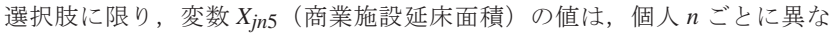
る通勤・通学駅周辺の商業施設の合計延床面積の值を用いている。

注 6) PT データによれば, 鉄道利用者の各トリップにおける発着駅（駅コー ド）を取得することができる。これを用いて，自宅，通勤・通学先，立 ち寄り先の最寄り駅を抽出している。

注 7）選択肢が多過ぎるとモデルの推定が困難となり，逆に，選択肢が少な 過ぎると，モデルの説明力が低下寸る。そこで，推定精度が低下しない 範囲で, 出来るだけ多くの駅を対象とするため, 本稿では 40 駅に設定し た。

注 8) 変数 $X_{j n 5}$ を算出する際に用いる建物現況調査データの対象地域が, 東 京都内に限られているため, 分析対象駅は東京都内の駅に限定している （居住地駅が東京都外の駅である場合は含む）。

注 9）例えばH20 については, PT データの全サンプル数は 733,873であり, そのうち，鉄道利用者のサンプル数は 196,819（26.8\%）である。また， 図 5 に示す条件を満たすサンプル数は 4,794であり, PT データ全体の $0.653 \%$ に相当する。S63, H10 の分析対象サンプル数についても, PT デー 夕全体からみた割合は同程度である。

注 10) PT データにおける交通手段の「徒歩」,「鉄道・地下鉄」以外の手段（自 転車など）を含む。

注 11）渋谷駅周辺地域では, 合計延床面積が約 90 万 $\mathrm{m}^{2} の$ 再開発計画がある。 建物用途は商業施設，住宅，事務所など様々であることから，既に竣工 している渋谷ヒカリエの商業施設の割合（約 $22 \%$ ) を参考にして，20万 $\mathrm{m}^{2}$ 程度の商業施設が建設されると想定した。ただし，実際には取り壊さ れる商業施設の延床面積分を考慮する必要があるので，大雑把ではある が，ここでは 10 万 $\mathrm{m}^{2} の$ 商業施設の純増を想定した。

\section{参考文献}

1）足立卓也・吉川徹：職住遊の配置に着目した立ち寄りや寸い都市空 間構成の分析, 日本都市計画学会都市計画報告集, No.14, pp.39-44, 2015.5

2）田中健一：首都圈鉄道駅の時空間的な立ち寄りやすさを測る, オレー ションズ・リサーチ：経営の科学, 55(3), pp.164-169, 2010.3

3）栗田治・本間裕大：立ち寄りを伴うトリップのための空間的相互作用 デルーウィルソンのエントロピー最大化法の一般化とその応用-, 日本 都市計画学会都市計画論文集, No.40-3, pp.109-114, 2005.10

4）小玉さと子・生田京子・山下哲郎：都市就業者の通勤実態とその行 動に関する一考察, 日本建築学会大会学術講演梗概集 E-1, pp.1061$1062,2006.7$

5）磯野雄人・岸本達也：立ち寄り利用を考慮した公共図書館の利用モ デルと最適配置の特性, 日本都市計画学会都市計画論文集, Vol.46, No.3, pp.415-420, 2011.10

6）徳永直子・貞広幸雄：選択行動モデルに基づいた立ち寄り利用施設の 最適立地, 地理情報システム学会講演論文集, Vol.11, pp.139-142, 2002

7）前川朝尚・倉内慎也：松山都市圈 PT 調査データに基づく平日の買物 行動の類型化と目的地選択特性分析，土木学会論文集 D3（土木計画 学) , Vol.67, N0.5, pp.I_749-I_757, 2011

8）李成・山本俊行・倉内慎也・森川高行：品目による相違と場所選択に 着目した買い物行動の分析, 土木計画学研究・論文集, Vol.21, N o.2, 2004.9

9) 土木学会土木計画学研究委員会 : 非集計行動モデルの理論と実際, 1984.5

10）大佛俊泰：都市防災計画のための鉄道利用者の時空間分布推定，日本 建築学会計画系論文集，Vol.74，No.635，pp.137-144，2009.1

11）鯉㴊正裕・加藤勲：移動軌跡データを活用した鉄道利用者の交通行動 把握，情報処理学会研究報告, Vol.2009-ITS-37, N 0.5

12) 岩淵紗葵・大佛俊泰・沖拓弥: 帰宅時における立ち寄り駅の魅力度分析, 日本建築学会大会学術講演梗概集, 都市計画, pp.621-622, 2015.9

13）岩淵紗葵・大佛俊泰：鉄道利用者の帰宅途中における立ち寄り駅の 魅力度分析, 地理情報システム学会講演論文集（CD-ROM），Vol.24， F-3-2, 2015.10

14）岩淵紗葵・大佛俊泰・沖拓弥：駅周辺環境を考慮した帰宅時における 立ち寄り駅選択モデル, 日本建築学会大会学術講演梗概集, 都市計画, pp.209-210, 2016.8

15）岩淵紗葵・大佛俊泰・沖拓弥：通勤・通学者の帰宅時における立ち 寄り駅選択行動と地域分析, 地理情報システム学会講演論文集（CDROM ) , Vol.25, E55, 2016.10 


\title{
CHOICE BEHAVIOR OF STOPOVER-STATION BY RAILWAY USERS ON THEIR WAY HOME
}

\author{
Toshihiro OSARAGI*, Saki IWABUCHI ${ }^{* *}$ and Takuya OKI ${ }^{* * *}$ \\ * Prof., School of Environment and Society, Tokyo Institute of Technology, Dr. Eng.
** Grad. Student, Graduate School of Information Science and Engineering, Tokyo Institute of Technology \\ $*_{* *}$ Assist. Prof., School of Environment and Society, Tokyo Institute of Technology, M. Eng.
}

Railway commuters to work place/school, who are the majority of railway users, often make stopover at various stations for eating or shopping on their way home. In recent years, the mobility of railway users has been diversified by expansion of railway network and redevelopment around railway stations. Therefore, we need to analyze such stopover behavior by commuters in order not only to improve safe and comfortableness of railway stations but also to activate the commercial activities in the vicinity of stations.

In this paper, we constructed a multinomial logit model, which describes commuters' choice behavior of stopover-stations for eating or shopping on their way home from their workplace. More specifically, we considered commercial facilities in the vicinity of the stopover-station and the positional relationships between their home and workplace as explanatory variables. A nalyzing the person trip data obtained in three different time $(1988,1998$, and 2008) in Tokyo M etropolitan A rea by the proposed model, we demonstrated the estimation accuracy of the model and the attractiveness of stopover-stations quantitatively. On the basis of the estimated parameters, we grasped the influence of each variable on the attractiveness of stopover-station in three different time. For instance, it is shown that transfer stations, stations located on a railway line of their way home, and stations surrounded by many commercial facilities were attractive for stopover. By contrast, the effects of resistance to the increase of travel time is getting larger and larger.

Furthermore, we classified the samples of railway users by his/her personal attribute (gender, age, and the purpose of stopover), and estimated the stopover behavior model for each attribute. M ore concretely, we quantitatively analyzed the preference for choosing stopover-station, and obtained the new findings as follows:

(1) Men prefer to make stopover at transfer stations on their way home, but women prefer stations which are surrounded by many commercial facilities with large total floor area.

(2) Elderly people are reluctant to increase of travel time by stopover, and stations with high commercial potential are more attractive for young people.

(3) People who make stopover for shopping tend to feel higher resistance to the increase in travel time by stopover. On the other hand, transit stations, which are convenient for meeting friends, are more attractive for people who make stopover for eating, socializing, or entertainment.

Finally, as an application of the proposed model, we estimated the change of attractiveness of stopover-stations and the number of people who made stopover. Namely, assuming that the number of commercial facilities around the specific station increased, the attractiveness of the station and other adjacent stations on the same railway line tended to be decreased greatly. Additionally, assuming that the mutual railway line operation between different railway companies started, stations on the direct railway line became more attractive for stopover, but the attractiveness of stations on other railway lines were decreased. Through these examples of simulation, we demonstrated the possibilities of application of stopover behavior model proposed in this paper. 